\title{
Gendered economy in the Mosquitía: women's roles in a changing indigenous economy
}

\author{
Economía de género en el Mosquitía: papeles femeninos en \\ una economía indígena que se cambia
}

\author{
Ariana Toth ${ }^{1}$ \\ Giffels Webster, Detroit, MI, USA
}

\begin{abstract}
This paper explores first hand perceptions of Nicaraguan Miskitu women's role in their local economy. Attention is paid to how economic practices have changed over time and whether change spurred by outside influences - such as corporate ventures and NGOs - have eroded the authenticity of an indigenous economy. Some historical economic practices are explored with a focus on the post-war economy and how political autonomy has affected women's role. Surveys of Miskitu women obtained during field research, with support from relevant literature, comprise the main source of information considered.
\end{abstract}

Keywords: Miskitu, indigenous economy, autonomy, women

\section{Resumen}

Este papel explora percepciones primero de mano del Nicaragüense Miskitu papel femenino en su economía local. La atención es prestada a como las prácticas económicas se han cambiado con el tiempo y si el cambio espoleado por influencias exteriores - como empresas corporativas y NGOs - haya erosionado la autenticidad de una economía indígena. Algunas prácticas económicas históricas son exploradas con un foco en la economía de la posguerra y como la autonomía política ha afectado el papel femenino. Las revisiones de mujeres de Miskitu obtenidas durante la investigación de campaña, con el apoyo de la literatura relevante, comprenden la fuente principal de la información considerada.

Palabras Clave: Miskitu, economía indígenas, autonomía, mujeres

1 Giffels Webster, Detroit, MI, USA. Email:arianamtoth@gmail.com

Este artículo corresponde a la ponencia presentada en el 35th Conference of Latin American Geographers realizada en San José, Costa Rica del 20 al 22 de mayo del 2018. 
If village economic organization continues to change toward monetarybased market transactions at the expense of reciprocal exchange, then its social complement will be the increased individualization of households, the fragmentation of community structure, and possible rearrangement or termination of subsistence economy-embedded social relationships (Nietschmann, 1973, p. 194).

The lands inhabited by the Miskitu population span Southeastern Nicaragua along the Atlantic Coast northward into Honduras. This paper investigates the Miskitu women of the North Atlantic Autonomous Region (RAAN) in Nicaragua and their role in their local economy as it relates to individual economic autonomy and social status. It revisits Nietschmann's prediction from 1973 and explores the current situation through field research conducted by the author in 2012. During this time in the field, interviews were conducted with nine indigenous women plus a few officials. I was privileged to be able to conduct a short but invaluable interview with Mirna Cunningham Kain, who was serving as the Chair of the United Nations Permanent Forum of Indigenous Issues, the President of the Center for Autonomy and Development of Indigenous Peoples (CADPI), among other prominent leadership roles (Cunningham, 2012).

Some historical context regarding the integration of subsistence and market economies by the Miskitu is available in the literature and relevant to this study. However, since next to nothing is known for certain about the pre-contact economic or cultural practices of the Miskitu, much of the accepted knowledge about this evolution is informed conjecture. It is believed that the Miskitu had a subsistence and barter-based economy prior to contact with Europeans (Nietschmann, 1973, pp. 29-30). From the post-contact period we know that trade was established early on with buccaneers and the British, and that this eventually turned into a cash-based system which also allowed for the exchange of labor for wages (Nietschmann, 1973, pp. 35 40). Eventually, Miskitu people became dependent upon foreign manufactured goods, at which point Helms labels theirs a purchase economy (Helms, 1971). Despite this long history with market-based trade, wage labor, and export of natural resources, cash-based transactions were primarily limited to exchanges with foreigners while economic transactions within villages remained based on reciprocity and barter (Nietschmann, 1973, p. 196). Even 
when cash was first integrated into the exchange of resources between members of a community, the new market economy was not independent of social ties and kinship (Nietschmann, 1973, p. 197).

Due to the boom and bust nature of foreign trade in the region, there were lengthy periods when money was scarce and people had to rely mainly on subsistence practices. A result of this is the realization of poverty and the attending psychological effects of deprivation (Helms, 1971, p. 156).

\section{Economic Characteristics}

The heart of the Miskitu community is the concept of reciprocity, solidarity, and benefit sharing, which the Miskitu call pana-pana; "this principle is the one that ensures the concept of collectivity" (Field Note 7). When I asked Mirna Cunningham what aspects of the culture were being lost due to Westernizing influences it was this fundamental principal that she cited, "That concept of collective wellness is something that people are losing. They don't care anymore if somebody doesn't have, if the other one doesn't have, as long as they have" (Field Note 7). What's more, she told me that "this whole concept of pana-pana, of sharing, is a responsibility of women; and that is part of the indigenous economy" (Field Note 7). This perspective of the diminishing observation of pana-pana is corroborated by the women of Tuapi (Fenly, IIWF, \& CADPI, 2011).

Within Miskitu gender ideology, it is believed that men should provide financially for the women. Many Miskitu women seek out men to provide for them (Field Note 5). Transactional sexual relationships in which the man gives the woman a "present" of money as a symbol of his love are one method women use to gain access to cash resources (Herlihy, 2012, pp. 127-128).

Rural men often work as migrant wage-laborers while the women stay home and raise the children and manage the household (Herlihy, 2012). However, migrant wage-labor was more common during Company Time (1920-1979) than now. Presently, people living in rural communities are reverting to a more subsistence lifestyle (Nietschmann, 1973).

One woman surveyed told me that the attitude of many men conforms with the concept of chamba, that you're not sure about the future but today you have enough (Field Note 5). These men do not feel compelled to plan for the future because they are not faced with immediate want, whereas women are more likely to plan for the future due to a stronger focus on 
their children's wellbeing. I was also told that single women must provide for themselves and therefore have control over their own money, unlike married women who must rely upon their husbands (Field Notes 8,10 ).

The existing literature presents conflicting views of women's access to money. In Kuri, Honduras, Herlihy found that, "Women head households, make all child rearing and economic decisions, and eventually gain control of the men's winnings" (Herlihy, 2006, p. 145). Likewise, in Tasbapauni, in the RAAS, men are said to hand money over to women for consumption, implying that women do not need to enter the workforce themselves in order to access cash (Henricksen \& Kindblad, 2011). However, as in most societies, Miskitu women are restricted by a gendered division of space. Tradition dictates that the woman's place is in the home (Field Notes 6, 7, 10; Helms, 1971; Herlihy, 2006). One woman I surveyed in Bilwi said that while men might hand earnings to women in some communities, since only men travel to tawans, like Bilwi or Waspam, to spend the money they have ultimate control over household spending (Field Note 10). This is because most tawan sirpis ${ }^{2}$ do not have stores and so people have to travel to the larger tawans to purchase items they are unable to produce themselves, such as clothes and some food goods, including cooking oil, salt, and sugar (Field Note 6). Tawan sirpis also lack banks. Women's limited movement therefore usurps their household economic authority. However, I was told by the one Mayangna woman I surveyed that she administers the money for the family even though only her husband (a Miskitu man) has an income (Field Note 8).

Laura Herlihy found in Kuri that women "are adapting to the market economy by incorporating modern resources into their reciprocity networks" (Herlihy, 2012, p. 95). This conflicts somewhat with Kindblad's description of the replacement of the traditional economy with a new cash-based economy in Tasbapauni, RAAS, Nicaragua. In Bilwi, I witnessed a lot of cashbased commerce. However, this is the largest city in the RAAN and therefore not very representative of the overall economy. Unfortunately, I was unable to spend enough time in rural communities to get a good first-hand account of how much the market economy has penetrated everyday life there.

Regardless of who handles the money for the family, it should only be spent for basic needs. Mirna Cunningham told me that one of "the

2 The plural of tawan sirpi in Miskitu is actually tawan sirpi nani. I will use the conventional English form of pluralization by adding an 's' to Miskitu words for ease of comprehension.

128 Revista Geográfica de América Central Nº 61E (3) Especial CLAG e-ISSN 2215-2563 • Julio-diciembre 2018 • pp. 125-135 Doi: http://dx.doi.org/10.15359/rgac.61-3.7 
elements of indigenous economy is no accumulation - if you accumulate you have to share, even if it's with a party" (Field Note 7). This might still be the norm in most tawan sirpis but judging by what I was told from the women I surveyed in Bilwi it seems that the community structure there is less cohesive. This seems to lead to more income disparity within the city.

\section{Rits}

I was also informed that the Miskitu economy is very dependent upon natural resources (Field Note 1). This statement agrees with the literature such that since "the main economic asset in this community, land, has for many years also been a main ingredient in local constructions of ethnicity and ethno-political identities... the study of economic and cultural aspects must be inseparable" (Henricksen \& Kindblad, 2011, p. 193). A focus group of women in Tuapi revealed the following uses of the land,

The indigenous women of the Tuapi community perceive the forest as their main means of subsistence since the forest is the site of agricultural land that they use for their plantations, the source of wood to construct their homes, firewood and medicinal plants to cure illnesses. They also depend on the forest for wild animals that they hunt according to the season. Aside from hunting, they gather wild fruits which they sell at the local market in the town of Bilwi. (Fenly, IIWF, \& CADPI, 2011, p. 52)

The younger generations do not have the same connection to nature and Yapti Tasba, Mother Earth, as did their ancestors (Cunningham Kain, 2011). Due to the large-scale abandonment of traditional spiritual beliefs, many also no longer have the same level of respect for the trees and fear of the spirits who were said to live in the forests (Cunningham Kain, 2011). This change in attitude has allowed logging and other capitalist enterprises to destroy parts of the environment that used to be revered by the ancestors (Cunningham Kain, 2011). A key distinction here is that indigenous people, including the Miskitu, view nature as a living thing in which humans must live in harmony, as opposed to the Western view of the environment as a resource that exists for human use (Tebtebba Foundation, 2010; Escobar, 1995).

Since many people still rely on subsistence practices, the resources provided by the land are essential to their livelihood. One of the women 
I spoke to estimated that about half the Miskitu people have a subsistence lifestyle while the other half are professionals (Field Note 11). She said the lifestyle is part of what makes Miskitu culture unique, indicating that it is being lost as younger generations tend towards professionalism. As is the case with many indigenous peoples, the Miskitu believe the forests "were once dense and filled with animals, with many sections known as the places inhabited by beings (spirits, sprites, liwa mairin ${ }^{3}$, unta dukia ${ }^{4}$, and others) who are the care-takers of the forest and waters" (Cunningham Kain, 2011, p. 9). Today however, resources are more scarce due to both overuse and climate change (Cunningham Kain, 2011). In the Miskitu language the word for natural resources, rits, is the same word used to indicate wealth. This is a telling indication of the value placed on the sustenance that the land provides.

I was also told that women want more input in how the natural resources on their land are used (Field Note 2). Currently, only men have a say in whether resources will be sold off the land according to two of the women with whom I spoke (Field Notes 2, 8). A third woman from the tawan sirpi of Kamla told me that the sindico, theirs happens to be a woman, decides about the rits in their community (Field Note 9.) A fourth woman who used to work in rural communities teaching women how to administer natural resources said that women have more control over the natural resources than the men because women are more likely to plan for the future whereas men are primarily concerned with how to make a profit from the resources currently available (Field Note 10). This statement reinforces the prevalence of the chamba attitude among Miskitu men. (I believe this woman's answer likely indicates her opinion of who should have more control over natural resources rather than who actually does. This could be due to a flaw in the translation of the question, since her survey was conducted in Spanish, or it could be a due to her own misinterpretation of the question.) Other women surveyed did not have first-hand knowledge pertaining to how much control women have over the use of community resources. According to Mirna Cunningham, on the whole, women do not have any say over how natural resources are used (Field Note 7). It is important to note again that this is only in reference to commercial use of natural resources. Women as well as men have the ability to gather any

$\begin{array}{ll}3 & \text { "Mermaid". } \\ 4 & \text { Literally, "forest thing"; the owner of the forest. }\end{array}$

130 Revista Geográfica de América Central No 61E (3) Especial CLAG Este artículo está bajo una licencia e-ISSN 2215-2563 • Julio-diciembre 2018 • pp. 125-135 Atribución/Reconocimiento-NoComercialDoi: http://dx.doi.org/10.15359/rgac.61-3.7

Compartirlgual 4.0 Internacional 
resources they need for their own homes from their lands, but they do have to pay a tax for that use, according to one of the women I surveyed in Kamla (Field Note 9).

The regional government used to have the power to decide how natural resources were used throughout the RAAN (Field Note 1). Now those decisions are made by the territories and if the regional government wants access to the resources of a given community they must have party members influence local leaders to allow that access (Field Note 1). This change was made to protect the communities from exploitation at the regional level. This, though, has led to political corruption as a common theme in many of the problems that the RAAN faces.

\section{Wage Labor}

Of the nine women I surveyed, six of them were employed at least part-time; one was an unemployed student at URACCAN, and one was employed as a teaching assistant at the university she attends in the United States. The ninth woman told me that she does not have a job; she only has temporary vocational work. She believes she was fired from her job for political reasons so she now cares for therapy patients in her home when she is able to find any and also does some volunteer work as therapist on the radio. I was told by one woman that "My people like to work" (Field Note 5). She identified many problems that limit this ability: "most women don't have a good education;" "there is no employment for anyone;" "There is good land here, lots of natural resources, including the sea. There is good land for planting plus woods, but the government does not have an initiative for this" (Field Note 5). She went on to say that "now the indigenous people can't hunt in the bush because it's being cut down, which causes the river to close up and makes people more poor" (Field Note 5). So according to her, not only are there no job opportunities but traditional subsistence livelihoods are also at stake due to the capitalist exploitation of their natural resources. However, she does not blame outsiders for these conditions, "indigenous people do this to each other," she said (Field Note 5). She blames current conditions on corrupt politicians in the regional government. It is her opinion that poverty is a problem because the government does not look for ways for people to be employed nor do they attempt to establish negotiations or contracts with foreign companies (Field Note 5). 
Two of the women I surveyed had moved to Bilwi as single adults to obtain a wage-paying job so they could send either goods or money back to their families. The fact that they are both single is significant since married women do not have the same freedom of movement or control over their own income that single women possess. These particular women moved from Sandy Bay and from Wangki ${ }^{5}$. The woman from Wangki said she uses the money she earns to send clothes and food products that her family is unable to grow back home; she does not send cash since there is no store in their community (Field Note 13). The woman from Sandy Bay said that she sends money back to her grandparents since there is a store in their community where they can purchase items they are unable to produce themselves (Field Note 14). They both told me they work eleven hours a day, six days a week as a helper in another family's home. Their work entails washing clothes, cleaning the house, cooking meals, and watching the family's children (Field Notes 13, 14). Both of these women told me that there is no work for women in their home communities and as a result a lot of people, mostly women, are moving to cities for wage labor (Field Notes 13, 14).

The woman from Sandy Bay told me that there is no work available for women in her community and therefore the women there are not economically independent (Field Note 14). She also said that the women there need all kinds of outside help because they have a lot of problems there, including a lack of food (Field Note 14). However, the woman from a Wangki riverine community, where there is no store, said that a lot of women in her community are economically independent and that they work the lands planting beans (Field Note 13). She further told me that the men there clear the lands and sometimes work mining gold (Field Note 13). She said that the women in her community do not require any outside help due to these conditions (Field Note 13). This information supports the theory that creating opportunities to obtain paid work does not always lead to more gender equality.

Marlon, a local half-Miskitu man and student at URACCAN who I hired as a translator, informed me that the main occupations available in

5 Even though this woman said that Wangki is the "tawan" she is from I believe it is more likely the territory and that she is actually from a smaller tawan sirpi. This assumption is due to the fact that she said her home community does not have stores and I saw stores in the tawan of Wangki when I was there. 
Bilwi are teachers, nurses, fishing, lobster diving, police, government jobs, reverend/minister, or as students (Field Note 6). He believes that about $40 \%$ of the population in Bilwi live in the tawan but have families in a tawan sirpi and go back home to work their insla, or farm (Field Note 6). Some of these jobs, such as lobster diving, are only available to men. I was told that while there are some women who are working in the fishing industry they are more susceptible to acts of violence since coastal fishing is viewed as the domain of men (Field Note 1). This seems to apply solely to the act of fishing, though and not the industry in general, as I saw many women shelling conchs at the seafood factory I was able to tour. Marlon said there are also a lot of people who move to Bilwi to study and go to school since there is a university in the town (BICU) and another nearby (URACCAN) (Field Note 6).

More women are attending universities and seeking professional careers, especially in the city. In an interview with Herlihy, Mirna said that "The main accomplishment of women in the last twenty-five years is that they have become more visible" (Herlihy, 2011, p. 221). This trend will allow upcoming generations of women to be more financially autonomous.

\section{Conclusions}

Mirna said, "In a way autonomy is like a tricky set-up because it gives back the responsibility to the communities. But in the communities women have a very weak position" (Field Note 7). In practice, this means that Miskitu women's status - economically, politically, socially - will continue to vary based on location within the RAAN.

One of the most important aspects of Miskitu laws and traditions is their variability over space. While there are many similarities between the laws and traditions of Miskitu people from different tawans and tawan sirpis, enough to provide a clear cultural homogeneity, there is enough differentiation that generalizations about the economic and political status of women cannot be made regarding the entire region at this point in time.

The current economic situation has been caused by outside disturbance through the imposition of wage labor practices by foreign corporations. The practice of pana-pana has thus deteriorated with the continued promotion of a market economy by outside actors. The Western concept of Progress is synonymous with increased capital production through 
neoliberal policies implemented by Western agencies. While the Miskitu have historically managed to balance a market-based exchange with foreigners and the protection of their cultural values and practices by limiting their integration of free-market-based monetary transactions into interpersonal economic relationships, this has been rapidly changing in recent years. A consequence of this change is the increasing decline in reciprocity networks accompanied by heightened individualism.

Through my research, I found that Nietschmann's prediction that increased activity in the wage economy has continued to threaten the Miskitu system of pana-pana. What's more, this practice of reciprocity is mainly the responsibility of women. This could mean that Westernization is not only threatening the communal nature of the Miskitu, but actually eroding women's economic role and authority within the community.

\section{References}

Cunningham Kain, R. (2011). The Grandmothers of the Wangki. In T.

Foundation, Indigenous Women, Climate Change and Forests (pp. 3-40). Baguio City, Philippines: Tebtebba Foundation.

Cunningham, M. (2012). Knowing Mirna Cunningham. Retrieved from

Mirna Cunningham: www.mirnacunningham.org

Escobar, A. (1995). Encountering Development: The Making and Unmaking of the Third World. Princeton: Princeton University Press.

Fenly, N., IIWF, \& CADPI. (2011). Forests and Indigenous Women in Tuapi: "Return to Auhbi Piakan". In T. Foundation, Indigenous Women, Climate Change and Forests (pp. 41-74). Baguio City, Philippines: Tebtebba Foundation.

Helms, M. W. (1971). Asang: Adaptations to Culture Contact in a Miskito Community. Gainesville: University of Florida Press.

Henricksen, K., \& Kindblad, C. (2011). Neoliberalism, Patriarchal Rule, and Cultural Change at the Turn of the Twentieth Century: The Case of Tasbapauni. In L. Baracco (Ed.), National Integration and Contested Autonomy: The Caribbean Coast of Nicaragua (pp. 191-220). New York: Algora Publishing.

Herlihy, L. H. (2006). Sexual Magic and Money: Miskitu Women's Strategies in Northern Honduras. Ethnology, 45 (2), 143-159. 
Herlihy, L. H. (2012). The Mermaid \& the Lobster Diver: Gender, Sexuality, and Money on the Miskito Coast. Albuquerque: University of New Mexico Press.

Nietschmann, B. (1973). Between Land and Water. New York: Seminar Press. Tebtebba Foundation. (2010). Towards an Alternative Development Paradigm: Indigenous People's Self-Determined Development. (V. Tauli-Corpuz, \& L. d. Enkiwe-Abayao, Eds.) Baguio City, Philippines: Tebtebba Foundation.

\section{Field Notes}

1. Survey one. Conducted June 14, 2012, in Bilwi, in English.

2. Survey two. Conducted June 17, 2012, in Waspam, in English.

3. Informal lecture by American man on June 20, 2012, in Bilwi, in English.

4. Avelino Cox Molina. Lecture on June 30, 2012, in Bilwi, in Spanish and translated by a fluent speaker among the study abroad students.

5. Survey three. Conducted July 9, 2012, in Bilwi, in English.

6. Marlon Dalvez Cassanova. Multiple conversations taking place over six weeks with one interview session on July 13, 2012, in English.

7. Interview with Mirna Cunningham Kain. Conducted July 16, 2012, in Bilwi, in English.

8. Survey four. Conducted July 16, 2012, in Kamla, primarily conducted in Miskitu with translations by Marlon Dalvez Cassanova.

9. Survey five. Conducted July 16, 2012, in Kamla, in Miskitu with translations by Marlon Dalvez Cassanova.

10. Survey six. Conducted July 18, 2012, in a barrio of Bilwi, in Spanish with translations by Marlon Dalvez Cassanova.

11. Survey seven. Conducted July 21, 2012, at URACCAN, in Miskitu with translations by Marlon Dalvez Cassanova.

12. Conversation with minister of Creole Moravian Church in Puerto Cabeza, July 22, 2012, in English.

13. Survey eight. Conducted July 24, 2012, in Bilwi, in Spanish with translations by Marlon Dalvez Cassanova.

14. Survey nine. Conducted July 24, 2012, in Bilwi, with introductory questions conducted in Spanish by author and complex questions in Miskitu with translations by Marlon Dalvez Cassanova. 
